\title{
Occurrence of Reciprocal Translocation in Lathyrus boissieri Sirj (Fabaceae) from Iran
}

\author{
Seyed Mahmood Ghaffari, ${ }^{1, *}$, Ghasem Karimzadeh ${ }^{2}$ and \\ Ali Akbar Najafi ${ }^{3}$ \\ ${ }^{1}$ Institute of Biochemistry and Biophysics, University of Tehran, P.O.Box 13145-1384, \\ Tehran, Iran \\ ${ }^{2}$ Faculty of Agriculture, Tarbiat Modares University, Tehran, Iran \\ ${ }^{3}$ Department of Plant Science, School of Biology, College of Science, University of \\ Tehran, Tehran, Iran.
}

Received March 16, 2008; accepted July 25, 2009

\begin{abstract}
Summary Diploid Lathyrus boissier showed the 7 bivalents in most of pollen mother cells at prophase and metaphase of meiosis. The disturbances in the meiotic stage appeared to have been caused by reciprocal translocation. Meiotic analyses of 232 pollen mother cells indicates occurrence of heterozygotic reciprocal translocation in 94 cells. When the crossing-over and chiasma formation take place in all 4 pairing segments, a ring of 4 chromosomes results, and when the chiasma was absent in one of the 4 pairing segments, a chain of 4 chromosomes results. Of the 94 transtocated MI cells examined, 24 had ring quaderivalents, 55 had open chain quaderivalents and 15 had alternate (zigzag) ring quaderivalents. From the present investigation it appears L. boissier has not acquired stability as yet and translocation has played an important role in its evolution. In this study chromosome count and meiotic behaviour of $L$. boissieri is presented here for the first time.
\end{abstract}

Key words Fabaceae, Lathyrus boissieri, Meiosis, Reciprocal translocation.

Lathyrus L., from the viewpoint of taxonomy, is placed in the tribe of Vicieae which is in the Fabaceae (Leguminosae) family. It contains about 150-160 species of annual and perennial, autogamous and alogamous herbaceous creeping plant, which occur throughout the temperate regions of the Northern Hemisphere with 52 species in Europe, 30 species in North America, 78 species in Asia, and 24 species extending into tropical East Africa and 24 species into temperate South America (Kupicha 1983, Goyder 1986, Sahin et al. 1998, 2000, Badr 2006). The main centers of diversity are the Mediterranean region, Asia Minor and North America, as well as temperate South America and East Africa (Kupicha 1977, 1981, Jackson and Yunus 1984, Yamamoto et al. 1984, Simola 1986, Schifino-Wittmann et al. 1994, Klamt and Schifino-Wittmann, 2000). There are many species cultivated for forage and human food: L. sativus (grass pea), L. hirsutus (rough pea), L. cicera (flatpodded vetchling), L. odoratus (sweet pea), L. ochrus (ochrus), L. sylvestris (flat pea). Flora Iranica, possessing more than 22 species of the genus Lathyrus, belong to nine sections (Neamati 2000). Lathyrus boissieri, from the viewpoint of taxonomy, is placed in the section Lathyrostylis (Griseb.) Bassler. This taxon is distributed in Iran, Iraq, Turkey and Syria as natural herbaceous. Cytological investigations have shown that all species were diploid with $2 n=14$ chromosomes, that the basic chromosome number of $x=7$ is constant throughout the genus and that most of the species are diploid (Fedorov 1969, Ornduff 1968-1969, Moore 1970-1977, Goldblatt 1981-1988, Goldblatt and Johnson 1990-2003, Badr 2006, 2007) and some species are natural autopolyploids (Khawaja et al. 1995, 1997, 1998). Some of the diploids have

\footnotetext{
* Corresponding author, e-mail: ghaffari@ibb.ut.ac.ir
} 

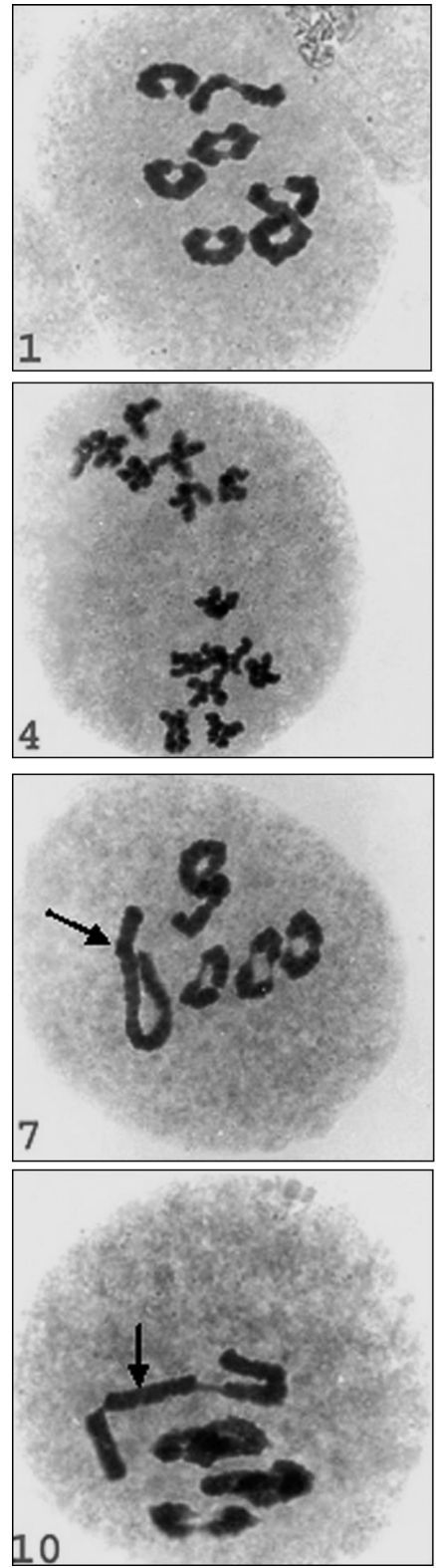
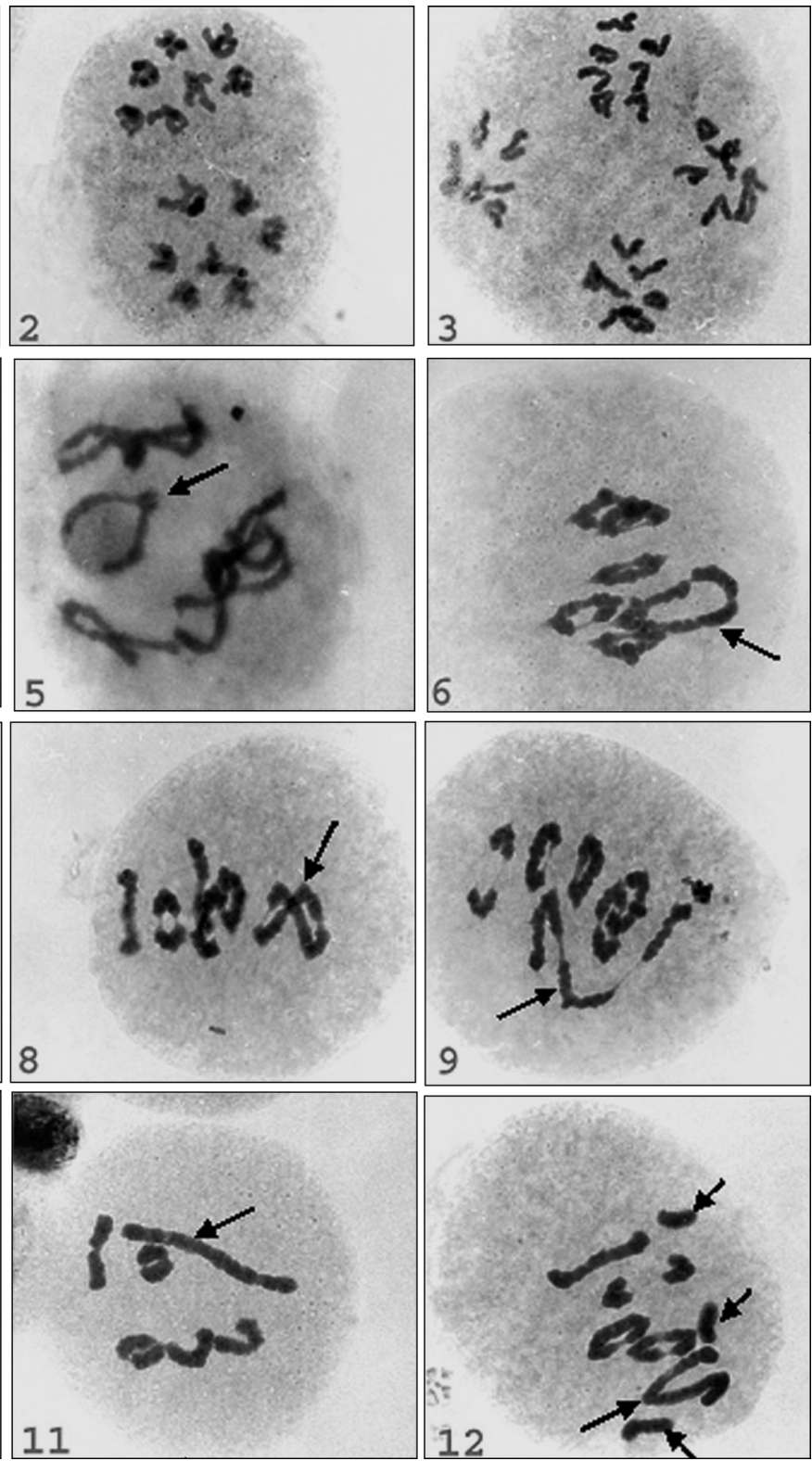

Figs. 1-12. Meiosis. 1. Metaphase I, showing 7 bivalents. 2. Anaphase I, showing 7-7 chromosome segregation. 3. Anaphase II, showing 7 monads segregation. 4. Metaphase II, showing 7 dyads in each pole. 5. Diakinesis, 1 bivalent associated with nucleolus (arrow). 6. Metaphase I, showing ring quaderivalent (arrow). 7. Meta-phase I, showing open chain quaderivalent (arrow). 8. Metaphase I, showing alternate (zigzag) ring quaderivalent (arrow). 9. Metaphase I, showing adjacent disjunction (arrow). 10. Metaphase I, showing alternate disjunction (arrow). 11 . Metaphase I, showing rod-shaped quaderivalent (arrow). 12. Metaphase I, showing trinalent (long arrow) and univalents (short arrows). Initial magnification $\times 320$.

been doubled artificially by colchicines treatment (Khawaja et al. 1997). Aneuploids are regularly formed in population of autotetraploids, including Lathyrus (Khawaja 1996, Khawaja et al. 1998). In this study chromosome count and meiotic behaviour of $L$. boissieri is presented for the first time. 


\section{Materials and methods}

Chromosome data has been obtained from 2 collections of L. boissieri. The first was a single plant origin of Khorramabad (Boojan), Loristan province. The second plant was collected from Avaj (Zanjan province). Floral buds of appropriate size were fixed in absolute ethanol : chloroform : propionic acid $(6: 3: 2)$ for $24 \mathrm{~h}$, transferred to $70 \%$ alcohol and stored under refrigeration until analyzed. Anthers were squashed and stained in $2 \%$ acetocarmine. Chromosome counts were carried out from microsprocyts in various stages of meiosis. Chromosomes were studied under oil immersion on an Olympus microscope at a magnification of 320X. Slides were made permanent by venetain turpentine according to the method of Wilson (1945). All slides are retained in the slide collection of the cytogenetics section of the Institute of Biochemistry and Biophysics (IBB). Figures for pollen sterility are based on a minimum of 750 grains stained with lactophenol-cotton blue. Voucher specimens are deposited in the Central Herbarium of Tehran University (HUT).

\section{Results and discussion}

The results obtained from meiotic studies in both 2 collections, showed the 7 bivalents in pollen mother cells at first metaphase (Fig. 1). Another stages of meiosis showed chromosome segregation (7-7) at anaphase I and 7 monads segregation at anaphase II (Fig. 2, 3). 7 dyads in each pole of second metaphase were observed (Fig. 4). In diakinesis substage 1 bivalent of chromosomes were associated with nucleolus (Fig. 5).

From the analysis of the dividing pollen mother cells it appeared that in nearly $59.48 \%$ of cell normal bivalent formation had taken place (Table 1). The number of ring bivalents in such pollen mother cells ranged from 5 to 7 and the rest were rod bivalents (Fig. 1). The mean number of chiasmata per cell and bivalents were 13 and 1.85 respectively. In $40.51 \%$ of PMCs at first metaphase univalent, trivalent and tetravalents were observed (Table 1). The disturbances in the meiotic stage appeared to have been caused by reciprocal translocation. It was observed that the abnormal PMC. generally carried tetravalents. The maximum association was found in the form of open chains consisting of 4 chromosomes. Of the 94 translo-

Table 1. Association of chromosomes at metaphase I

\begin{tabular}{ccc}
\hline \hline $\begin{array}{c}\text { No. of cells } \\
\text { analyzed }\end{array}$ & $\begin{array}{c}\text { No. of normal } \\
\text { cells }\end{array}$ & $\begin{array}{c}\text { No. of } \\
\text { abnormal cells }\end{array}$ \\
\hline 232 & 138 & 94 \\
$\%$ & 59.48 & 41.51 \\
\hline
\end{tabular}
cated MI cells examined, 24 had ring quaderivalents (Fig. 6), 55 had open chain quaderivalents (Fig. 7) and 15 had alternate (zigzag) ring quaderivalents (Fig. 8) (Table 2). According to Table 2, in most of the cases 4 chromosomes have been found to be associated in open chains $(58.51 \%)$, of which some of

Table 2. Interchange complex at M I in a heterozygous reciprocal translocation

\begin{tabular}{cccc}
\hline \hline $\begin{array}{c}\text { No. of cells } \\
\text { observed }\end{array}$ & $\begin{array}{c}\text { No. of PMC with ring } \\
\text { quaderivalent }\end{array}$ & $\begin{array}{c}\text { No. of PMC with chain } \\
\text { quaderivalent }\end{array}$ & $\begin{array}{c}\text { No. of PMC with zigzag } \\
\text { ring quaderivalent }\end{array}$ \\
\hline 94 & 24 & 55 & 15 \\
$\%$ & 25.53 & 58.51 & 15.95 \\
\hline
\end{tabular}

Table 3. Pollen stain ability

\begin{tabular}{cccc}
\hline \hline No. of pollen grains studied & No. of grains stained & No. of grains unstained & $\%$ of sterile pollen grains \\
\hline 750 & 482 & 268 & 35.73 \\
\hline
\end{tabular}


them may be the outcome of adjacent type of translocation (Fig. 9). These are supposed to be responsible for the formation of nonviable pollen grains containing duplication and deficiencies. Results indicates that 37 of the 55 open quaderivalents formed predominantly alternate orientations at first metaphase (Fig. 10), which is in agreement with the results obtained from the pollen stain ability (Table 3). The site of the chiasma formation and of the break in each chromosome may be responsible for the different frequencies of the alternate configuration of the interchange complex in these species. Occasionally in rare cases rod-shaped quaderivalents were observed (Fig. 11). According to Table 3, pollen fertility recorded in our sample showed a value of $64.26 \%$. Here, the presence of trivalents and univalents in rare cases may be explained on the basis that either translocations occurred in 4 chromosomes out of which, involved, leaving the remaining 1 'free' at the time of pairing (Fig. 12). In many plant species individuals with a reciprocal translocation are usually semi-sterile (50\% pollen and ovule abortion) and $50 \%$ of the meiocytes display the alternate configuration of the interchange complex at metaphase I. Also, in several plant species, plants with a reciprocal translocation are highly fertile and significantly more than $50 \%$ of the meiocytes have the alternate configuration (Sybenga 1992).

It is now evident from the above discussions that there is a definite tendency toward translocation heterozygosity in L. boissieri. Form the present investigation it appears L. boissier has not acquired stability as yet and translocation has played an important role in its evolution.

\section{Acknowledgements}

This work was supported by a grant (6401011/1/03) from the Research Council of the University of Tehran.

\section{References}

Badr, S. F. 2006. Karyotype analysis and chromosome evolution in species of Lathyrus (Fabaceae). Cytologia 71: 447-455.

- 2007. Karyotype analysis and chromosome evolution in species of Lathyrus (Fabaceae). Pakistan Journal of Biological Science 10: 49-56

Fedorov, A. A. (ed.) 1974. Chromosome numbers of flowering plants. Koeltz Scientific Books, Konigestein. pp. 926

Goyder, D. J. 1986. The genus Lathyrus. In: A. Kaul and D. Combes (eds.), Lathyrus and Lathyrism, 3-7. Third World Medical Research Foundation. New York, NY.

Goldblatt, P. 1981, 1984, 1985, 1988. Index to plant chromosome numbers. 1975-1978, 1979-1981, 1982-1983, 1984-1985. Monogr. Missouri Bot. Gard. 5, 8, 13, 23.

- and Johnson D. E. 1990, 1991, 1994, 1996, 1998, 2000, 2003. Index to plant chromosome numbers. 1986-1987, 1988-1989, 1990-1991, 1992-1993, 1994-1995, 1996-1997, 1998-2000. Monogr. Missouri Bot. Gard. 30, 40, $51,58,81,94$.

Jackson, M. T. and Yunus, A. G. 1984. Variation in the grasspea (Lathyrus satvus L.) and wild species. Euphytica 33 549-559.

Khawaja, H. I. T. 1996. Aneuploidy in the genus Lathyrus, pp. 50-53. In: Khawaja, H. I. T. (ed), Lathyrus sativus and lathyrism in Pakistan. Pakistan Gen Soc. Islamabad.

—, Ellis, J. R. and Sybenga, J. 1995. Cytogenetics of natural autohexaploid Lathyrus palustris. Genome 38: 827-831.

—, Sybenga, J. and Ellis, J. R. 1997. Chromosome pairing and chiasma formation in autopolyploids of different Lathyrus species. Genome 40: 937-944.

- - - and - 1998. Meiosis in aneuploid of tetraploid Lathyrus odoratus and L. pratensis. Hereditas 129: 53-57.

Klamt, A. and Schifino-Wittman, M. T. 2000. Karyotype morphology and evolution in some Lathyrus (Fabaceae) species of southern Brazil. Genetics and Molecular Biology 23: 463-467.

Kupicha, F. K. 1977. The delimitation of the tribe Vicieae (Leguminosae) and the relationships of Cicer L. Bot. J. Linn. Soc. 74: 131-162.

- 1981. Tribe Vicieae. In: Polhill, R. M. \& Raven, P. H. (eds), Advances in Legume systematics. Part I. Royal Botanical Garden, Kew. pp 377-381.

— 1983. The infrageneric structure of Lathyrus . Notes from the Royal Botanic Garden, Edinburgh 41: 209-244.

Moore, R. J. 1970, 1971, 1972, 1973, 1974, 1977. Index to plant chromosome numbers for 1968, 1969, 1970, 1967-71, 
1972, 1973-74. Regnum Veg. 68, 77, 84, 90, 91, 96.

Ornduff, R. 1968, 1969. Index to plant chromosome numbers for 1966, 1967. Regnum Veg. 55, 59.

Sahin, A., Genc, H. and Bagci, E. 1998. Cytotaxonomic investigations on some Lathyrus species growing in the western Mediterranean and southern Aegean regions in Turkey. Acta Botanica Hangarica 41: 229-241.

- - - and - 2000. Cytotaxonomic investigations on some Lathyrus species growing in eastern Mediterranean and southern Aegean regions-II. Acta Bot. Gallica 147: 243-256.

Schifino-Wittmann, M. T., Lau, A. H. and Simioni, C. 1994. The genera Vicia and Lathyrus in Rio Grande do Sul (southern Brazil): cytogenetics of native, naturalized and exotic species. Rev. Brasil. Genet. 17: 313-319.

Simola, L. K. 1986. Structural and chemical aspects of evolution of Lathyrus species. In: Kaul, A. K. and Combes, D. (eds), Lathyrus and Lathyrism. Proceedings of the International Symposium of IBEAS (1985), Paris. pp. 225-239.

Sybenga, J. 1992. Cytogenetics in plant breeding. Springer-Verlag, Berlin, Heidelberg, New York.

Wilson, G. B. 1945. The ventain turpentine moumting medium. Stain Technology 20: 133-135.

Yamamoto, K., Fujiware, T. and Blimenrich, I. D. 1984. Karyotypes and morphological characteristics of some species in the genus Lathyrus L. Japan J. Breed. 34: 273-284. 